Alice D. Schreyer

\title{
What's So Special about Special Collections Librarians?
}

"What's So Special about Special Collections?" was the title for the inaugural issue of RBM in 2000 and a theme issue of American Libraries published that same year. ${ }^{1}$ A variation of the phrase served as the subtitle for a 2005 RBMS Preconference seminar. ${ }^{2}$ The question asks us to articulate what distinguishes special collections from other research library collections and services, and reminds us of the implied elitism in our professional vocabulary. With a healthy dose of irony, we are challenging long-standing assumptions of difference.

What's so special about special collections librarians? I want to consider education and training with a similar mix of faith and skepticism. What distinguishes special collections librarians and archivists who work in research libraries from other research library specialists? I believe there are qualities that all special collections librarians must have, as well as skills that are unique to the diverse jobs that we hold. These specialized skills can be related to format, function, subject, or language, depending on the needs of positions as varied as rare book cataloger, university archivist, metadata specialist, archival processor, conservator, reader services librarian, digital collections specialist, and curator of medieval manuscripts, photography and graphic arts, popular culture, or Western Americana. But special collection librarians also need qualities and qualifications that are essential for all professionals in twenty-firstcentury research libraries. Education and training for special collections librarianship cannot be separated from discussions of our identity, our mission, and our interrelationships with our professional colleagues. That is what makes the subject so interesting and so important for special collections librarians at every stage of their careers.

In 2001, under the leadership of Joe Hewitt, now emeritus associate provost for university libraries at the University of North Carolina at Chapel Hill, the Association of

1. RBM: A Journal of Rare Books, Manuscripts, and Cultural Heritage 1:1 (2000); American Libraries 31:7 (August 2000).

2. "Redefining Rare, or, What's So Special about that Collection." 
Research Libraries (ARL) formed a Special Collections Task Force. The group emerged from a symposium for library directors and special collections librarians held at Brown University earlier that year. The directors who attended that symposium agreed to develop an agenda in support of special collections and advocate it with institutional administrators and ARL colleagues. The goals set by the ARL Task Force include promoting special collections as fundamental to the mission of research libraries and exposing "hidden collections." Since then, ARL issued a statement titled "Research Libraries and the Commitment to Special Collections," and a multi-institutional grant proposal has been developed to pilot innovative approaches to tackling archival backlogs. ${ }^{3}$

The recruitment, education, and training for special collections librarians also was identified as an agenda item for the ARL Special Collections Task Force. Library directors perceived an impending crisis based on their recent experiences trying to fill administrative positions, as well as anticipated vacancies in the coming years. Responses to the 1998 survey, Special Collections in ARL Libraries, indicated that 94 respondents expected to fill 1.7 professional vacancies in the five years following the survey. ${ }^{4}$ These demographics, and concerns about "the next generation," parallel those in librarianship generally, where a 2003 study reported that 28 percent of managers in the 2000 ARL population will be 65 or older by $2010 .^{5}$ Moreover, four years ago, it looked as if a reduced number of institutions offering MLIS programs, and changes in the curriculum at existing library schools, threatened to all but eliminate traditional educational paths into special collections librarianship.

Anecdotal evidence suggests that applicant pools are large for the small number of entry-level professional positions, but finding well-suited candidates for middle and senior management roles often proves difficult. In addition to these pragmatic reasons for concern, ARL library directors as well as special collections librarians recognize that technological and programmatic changes are creating different expectations for the profession. What academic, professional, and personal qualifications are needed to meet them? The tight academic market makes librarianship an attractive alternative for recent $\mathrm{PhDs}$, and special collections positions increasingly require strong academic credentials to demonstrate firsthand knowledge of research methodologies and teaching experience, as well as subject and/or language expertise. How can we recruit individuals with appropriate backgrounds and prepare them, as well as develop those already in the profession, for new roles and responsibilities? What can be done to increase diversity? Is an MLIS degree needed?

3. See http://www.arl.org/collect/spcoll/ for Task Force charge, roster, meeting minutes and published documents.

4. Judith M. Panitch, Special Collections in ARL Libraries: Results of the 1998 Survey Sponsored by the ARL Research Collections Committee (Washington, D.C.: ARL, 2001), 19.

5. Stanley Wilder, Demographic Change in Academic Librarianship (Washington, D.C.: ARL: 2003), 42 
An advanced subject degree? Both? Is the answer the same for all positions, or for all institutions? These questions, too, are not unique to special collections.

In 2003, the ARL Task Force organized an invitational working meeting at the University of North Carolina, Chapel Hill, of library directors, special collections administrators, library school educators, and representatives of the Society of American Archivists (SAA) and the ALA/ ACRL Rare Books and Manuscripts Section (RBMS) to assess the environment for education and training of special collections librarians and to explore potential strategies. ${ }^{6}$ As a first step, the group brainstormed about competencies. The list quickly split into two broad categories, as follows:

1. "Generic" skills, needed by all research librarians: Planning and project management; assessment; flexibility; creativity and innovation; advocacy (ability to frame message); fundraising and development; digitization and technical skills; teaching and writing skills (research, thinking/organizing); understanding of organizational dynamics; budget and management skills; and political savvy.

2. Skills and competencies identified as unique to all or some positions in special collections: Intellectual curiosity that extends to deep interest in the "stuff"; language skills; basic knowledge of conservation principles and practice; familiarity with pertinent legal and ethical issues (such as appraisals, taxes, gifts, copyright); knowledge of history of the book; specific subject expertise; archival processing skill; willingness to accept the responsibility that artifacts impose; and appreciation of the role of special collections in scholarship and teaching.

Such an approach to competencies suggests that some skills can—or must-be learned in library or graduate school, or intensive courses that provide an introduction to research libraries, whereas others must be provided by courses aimed at special collections librarians. The word that seemed to distill the elusive, but essential, ingredient for success in special collections turned out to be pizzazz, but no one knew of a program granting a degree in this hot field.

In the summer of 2004, the British Library and the New York Public Library (NYPL) cosponsored a meeting focusing on the role of curators in the twenty-first century. ${ }^{7}$ This group also developed a list of general and special core values and skills:

- Subject/object expertise in a discipline pertinent to the collection

- Ability to communicate with a variety of constituencies at different levels

- Knowledge about the artifacts and how they were produced

6. See http://www.arl.org/collect/spcoll/tforce/mins1103.html for meeting summary.

7. See http://www.nypl.org/research/curator/ for transcript of meeting discussions. 
- Sense of passion: Someone who really loves the stuff

- Ability to work in a team and to take on different roles

- Common sense

- Ability to do bibliographic instruction and to teach

- Technological facility

- Knowledge of the legal environment in which objects are created and served

- Inquisitiveness-about the object, its audience, and its context

- Adaptability

- Political savvy

- Managing without authority

- Generosity

- Core values of librarianship, including intellectual freedom

- Professionalism

Many of these skills would have turned up on lists compiled a generation ago. Our predecessors set a high standard for passionate collecting, though we are redefining "rare" to build collections in many different formats and spanning a much broader range of time and subjects. Along with them, we understand that our custodial and stewardship roles incur obligations to creators, donors, and physical objects. Perhaps more than in the past, we view socialization into the shared values, vocabulary, and culture of librarianship as essential to successful collaborations. Most of the new skills — entrepreneurial, collaborative, technical, and teaching —also apply elsewhere in research librarianship and, perhaps, to many other professions. What is new is the recognition that special collections librarians need these skills in addition to content expertise and specialized professional knowledge.

The Chapel Hill and NYPL exercises reaffirm the paramount importance of passion for the "stuff" and understanding of how it was produced. Everything we do-select, acquire, describe, mediate, contextualize, authenticate, serve, conserve-depends on our ability to interpret, communicate, and represent the authentic attributes of artifacts. This, perhaps more than any other personal quality or body of academic and professional expertise, is "special" about special collections librarianship.

The ARL working group stressed the need for flexible, creative, collaborative approaches to recruiting, educating, training, and developing special collections librarians. Following one of its recommendations, I wrote a white paper that articulates the issues, identifies initiatives already in place, and suggests strategies to enhance and strengthen current efforts. ${ }^{8}$ Key points made in the white paper include:

8. http://www.arl.org/collect/spcoll/SCTF.ED.pdf. 
- Recruitment, education, and training are needed at all career levels. It is not enough to attract talented people with appropriate backgrounds and personalities to special collections librarianship; we must help newcomers build their careers by providing internships or other professional-level opportunities to prepare them for highly competitive entry-level jobs.

- We need to enhance and develop the skills of practitioners and prepare them to move into senior positions.

- No single group or program can accomplish all that needs to be done. Library schools, research libraries, professional organizations, and other groups are partners in education and training; and collaboration among them is the key to innovative approaches.

- RBMS and SAA are meeting an essential need by collecting and disseminating information about education and training opportunities, and developing data on the profession through surveys.

- Defining core competencies must be done by the professional organizations.

The white paper recognizes that Rare Book School at the University of Virginia plays a unique role in providing specialized training. ARL directors expressed a strong commitment to ensure its continued vitality; a number emphasized that RBS is essential to maintaining the quality of their staff. It also acknowledges that the Rare Books and Special Collections concentration offered by the Palmer School of Library $\&$ Information Science at Long Island University may be part of a larger trend toward increased interest in special collections in library schools.

A number of initiatives aimed at meeting recruitment, education, and training needs in research librarianship were noted in the white paper; others have emerged since its publication:

- The Council on Library and Information Resources (CLIR), in conjunction with a consortium of academic research institutions, is entering the second year of a postdoctoral fellowship program to establish "a new kind of scholarly information professional.” New humanities PhDs receive fellowships that include two intensive seminars aimed at immersing participants in issues of scholarly communication and research libraries.

- The ARL Academy: Careers in Academic and Research Libraries is a partnership between ARL and three library schools to recruit, educate, and train MLIS students whose previous educational and professional experiences will add value to academic and research libraries. 
- ARL is piloting an executive Research Library Leadership Fellows Program sponsored by five ARL libraries, designed to prepare the next generation of research library directors.

- A Study on Supply and Demand of Subject Specialists for Research Libraries is a research project funded by the Institute of Library and Museum Studies to provide data on both actual and projected demand and supply and develop recruitment and curriculum models that can be used nationwide.

- Several research libraries are expanding and formalizing efforts to recruit graduate students. For example, after a highly successful 2003 symposium, "How to Do Things with Books," Yale established an internship for Yale graduate students who have completed the course work for the $\mathrm{PhD}$ to work in a department of the library appropriate to their own academic interest. ${ }^{9}$

The ARL Special Collections Task Force began its work on education and training ready to recommend and pursue funding for a fellowship program and/or specialized immersion course. Instead, we decided to focus for now on monitoring, encouraging, and facilitating new and emerging programs and activities rather than compete for funds to establish parallel ones. Until these programs are further along, we won't know whether they are sufficient or what else is needed. RBMS has formed a task force on competencies in conjunction with representatives from SAA. Archival training is the subject of the extensive $A^{\star}$ Census. ${ }^{10}$ Meanwhile, the ARL Special Collections Task Force is tackling other issues closely related to our professional identity and values. Discussions about the Hidden Collections initiative suggested a perceived or real culture gap between special collections librarians and archivists. We want to probe this question and foster understanding of the "special" expertise each contributes to research librarianship.

I bring multiple perspectives to the topic of education and training of special collections librarians - as a member of the ARL Special Collections Task Force, as an educator who teaches special collections librarianship at Rare Book School, and as someone who recruits, hires, and trains special collections librarians. Though this paper summarizes initiatives that hold great promise for the profession's future, my firsthand experiences are even more encouraging. The newcomers to the profession I have had the privilege of meeting at RBMS preconferences, Rare Book School, and in my administrative capacity fill me with confidence that I will be able to retire with complete trust in the talent pool for my successor.

9. http://www.clir.org/fellowships/postdoc/postdoc.html; http://www.arl.org/olms/arlacademy/; http://www.arl.org/olms/rllf/; http://www.clis.umd.edu/news_events/IMLSgrant.html; http://www.library.yale.edu/lhr/jobs/intern/gradinternship.html.

10. http://www.archivists.org/a-census/index.asp. 